\title{
Infografis sebagai Pendukung Berita In-depth dalam Situs Tirto.id
}

\author{
${ }^{1}$ Riyanti Hayuning Pratiwi, ${ }^{2}$ Ferry Darmawan \\ ${ }^{1,2}$ Fakultas Ilmu Komunikasi, Universitas Islam Bandung, Jl. Tamansari No. 1 Bandung 40116 \\ E-mail:1riyantihp2096@gmail.com, ${ }^{2}$ ferry@unisba.ac.id
}

\begin{abstract}
Tirto.id is an online news site known for its infographics. The information contained in Tirto.id is generally an in-depth report that has a long duration of written characteristics. One of the interesting news is about the looting of warship carcasses in Indonesian waters titled "The Mystery of the Dutch War shipwreck in the Java Sea" issue of January 18, 2018. The news is Mnejadi exclusive report on Tirto.id. With a fairly long writing duration. However, the presence of infographics is one way to understand long stories more easily and quickly. Using the case study method, the study aims to see infographic functions in the news in-depth. The results found are: (1) The infographic presented Tirto.id in its in-depth writing has some characteristics such as the use of more formal layouts than other news infographic layouts, the input data contains the news value, And the use of bright colors and interesting illustrations; (2) The depth of information that is presented in-depth infographics is still lacking when compared to the depth of the news itself, but between infographics and their contents is complementary unity; (3) The use of infographics in an in-depth news is nothing but a reader's attention.
\end{abstract}

Keyword: case study, in-depth reportage, mystery, graphic design

\begin{abstract}
Abstrak: Tirto.id merupakan situs berita online yang dikenal dengan infografisnya. Informasi yang dimuat dalam Tirto.id umumnya merupakan laporan in-depth yang memiliki karakteristik tulisan dengan durasi panjang. Salah satu berita yang menarik adalah mengenai penjarahan bangkai kapal perang di perairan Indonesia berjudul "Misteri Raibnya Bangkai Kapal Perang Belanda di Laut Jawa" edisi 18 Januari 2018. Berita tersebut mnejadi laporan eksklusif Tirto.id. dengan durasi tulisan yang cukup panjang. Namun, kehadiran infografis merupakan satu cara memahami berita yang panjang lebih mudah dan cepat. Menggunakan metode studi kasus, penelitian ini bertujuan melihat fungsi infografis dalam berita in-depth. Hasil yang ditemukan adalah: (1) Infografis yang disajikan Tirto.id pada tulisan in-depth-nya memiliki beberapa karakteristik seperti penggunaan layout yang lebih formal dibandingkan layout infografis berita lainnya, data yang diinput memuat nilai berita, dan penggunaan warna-warna cerah serta ilustrasi yang menarik; (2) Kedalaman informasi yang disuguhkan infografis in-depth dirasa masih kurang jika dibandingkan dengan kedalaman berita itu sendiri, namun antara infografis dan isinya merupakan kesatuan yang saling melengkapi; (3) Penggunaan infografis dalam sebuah berita in-depth tidak lain sebagai penarik perhatian pembaca.
\end{abstract}

Kata Kunci: studi kasus, reportase mendalam, misteri, desain grafis 


\section{PENDAHULUAN}

Infografis merupakan satu dari sekian banyak produk yang dihasilkan dari ilmu desain grafis, yang merupakan bagian dari desain komunikasi visual. Menampilkan informasi yang dipadupadankan dengan visualisasi yang menarik bagi pembaca. Pengemasan infografis dibuat secara ringkas, padat, dan menarik sehingga pembaca mengetahui informasi yang disampaikan. Infografis menjadi cara baru dalam penyajian informasi di era milenial. Beberapa media massa yang kini menggunakan jasa media online atau sosial media, kini mulai melirik infografis sebagai media alternatif dalam menyampaikan sebuah pesan. Dalam berbagai berita, infografis dibuat dalam berbagai tampilan dan semenarik mungkin agar memikat perhatian pembaca, selain memudahkan pembaca memahami informasi. Berger menyatakan,

\begin{abstract}
"Much of we call 'information' (statistics and data) is based relationships. For example, suppose we are told that 50 percent of Americans earn $\$ 15,000$ a year. That piece of informatian doesn't tell us very much. Is \$15,000 a lot or a little? What does this figure mean? (We might think of information as involving data put into some kind relationship, given a context of some nature). If we are given information in words, it takes a good deal of mental work to make sense the numbers. Graphics such as bar charts, pie diagrams, and the like have a unique power to show relationships visually. We can see the relationships instantly, instead of having to do mental calculation" (Berger, 2008).
\end{abstract}

Tirto.id merupakan salah satu situs berita online di Indonesia sering menggunakan infografis di setiap beritanya. Media yang berdiri pada 3 Agustus 2016 ini menjadi situs berita yang berpedoman pada jurnalisme presisi atau jurnalisme data. Mengusung julukan "infografis ciamik", menjadi kelebihan lain yang dimiliki oleh Tirto.id. Tampilan halaman muka Tirto.id juga memiliki perbedaan dengan situs berita lain yaitu lebih didominasi gambar atau ilustrasi (GAMBAR 1).

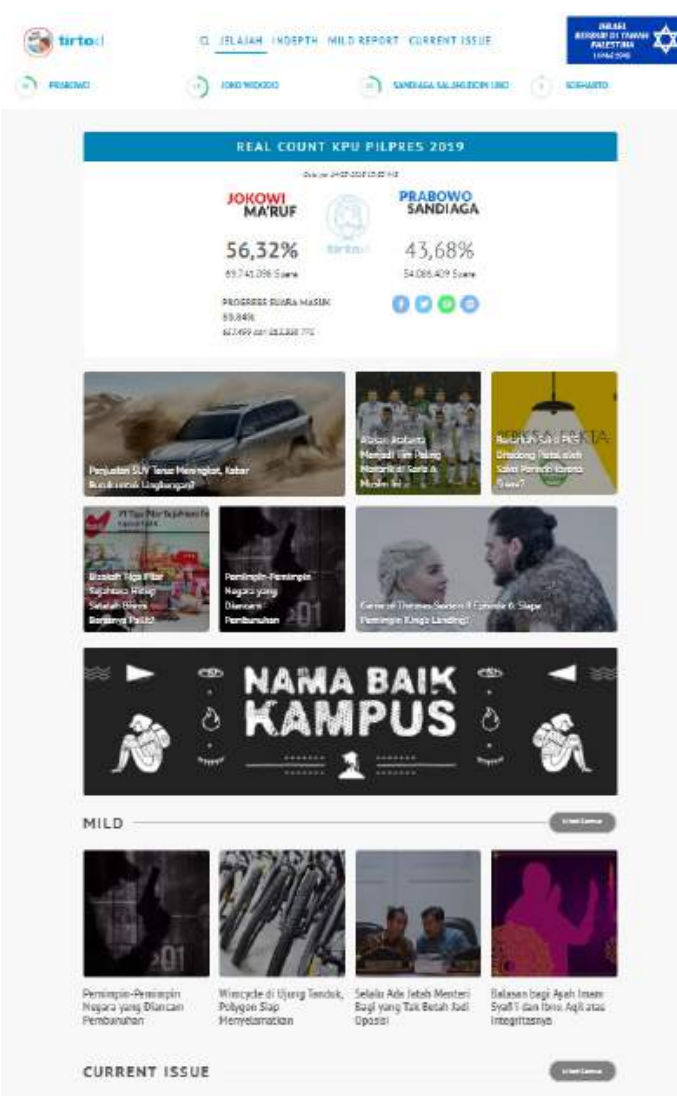

GAMBAR 1. Homepage Tirto.id

Selain itu Tirto.id juga dikenal sebagai salah satu media online yang menyajikan berita dengan isi laporan yang cukup panjang dibandingkan dengan media lainnya. Salah satu berita in-depth Tirto.id yang menjadi perhatian penulis adalah berita Misteri Raibnya Bangkai Kapal Perang Belanda di Laut Jawa edisi 18 Januari 2018. Berita ini merupakan salah satu dari rangkaian laporan eksklusif Tirto.id mengenai penjarahan kapal perang asing yang terjadi di Indonesia yang terdiri dari 6 judul tulisan. Tulisan ini menceritakan tentang salah satu perusahaan di Indonesia melakukan penjarahan bangkai kapal perang yang berada di beberapa titik di laut Indonesia. 
Hasil dari penjarahan tersebut dijual ke China yang disinyalir digunakan untuk kebutuhan pembangunan luar angkasa. Karena terdapat beberapa judul berita dan panjangnya durasi berita yang dibuat, pihak Tirto.id membuat halaman eksklusif yang dimuat di Tirto Visual Report (TVR) yang berisi infografis, visualisasi gambar, dan juga audio agar pembaca dapat memahami inti dari laporan tersebut. Peneliti memilih judul Misteri Raibnya Bangkai Kapal Perang Belanda di Laut Jawa karena ruang lingkup terjadinya masalah tersebut di Indonesia, dan juga dari 6 tulisan yang ada, tulisan ini didukung dengan infografis in-depth di dalamnya (GAMBAR 2).

Infografis merupakan satu dari sekian banyak produk yang dihasilkan

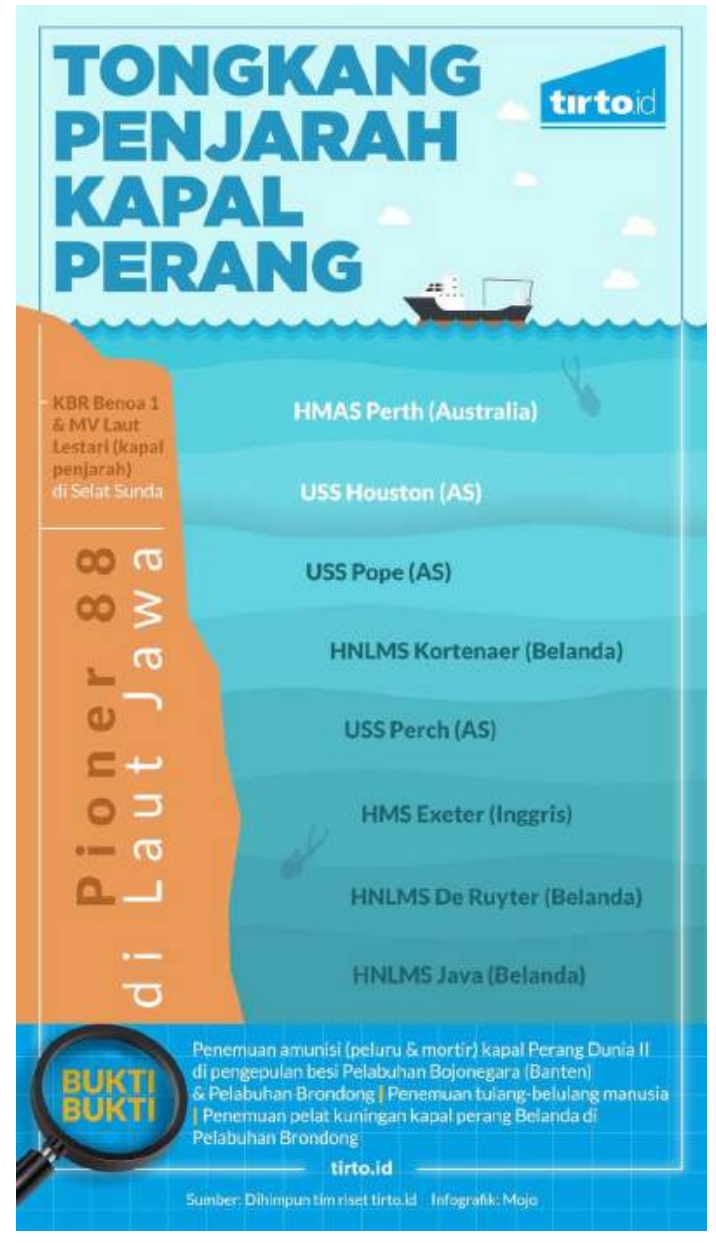

GAMBAR 2. Infografis dalam berita Misteri Raibnya Bangkai Kapal Perang Belanda di Laut Jawa edisi 18 Januari 2018 cabang ilmu Desain Komunikasi Visual (DKV). DKV dapat diartikan sebagai sebuah ilmu yang mempelajari dan mengembangkan bahasa komunikasi visual yang berbasiskan pengolahan pesan-pesan. DKV adalah ungkapan ide, dan pesan dari perancang kepada publik yang dituju melalui simbol berujud gambar, warna, tulisan dan elemen visual dasar. DKV adalah ilmu yang mempelajari konsep komunikasi dan ungkapan daya kreatif yang diaplikasikan dalam pelbagai media komunikasi visual dengan mengolah elemen desain grafis yang terdiri dari gambar (ilustrasi), huruf dan tipografi, warna, komposisi dan layout. DKV adalah suatu disiplin ilmu yang bertujuan untuk mempelajari konsep-konsep komunikasi serta ungkapan kreatif melalui berbagai media untuk menyampaikan pesan dan gagasan secara visual dengan mengelola elemenelemen grafis yang berupa bentuk dan gambar, tatanan huruf, serta komposisi warna dan layout (tata letak/perwajahan). Dengan demikian gagasan bisa diterima oleh orang atau kelompok yang menjadi sasaran penerima pesan. DKV merupakan seni dalam menyampaikan informasi atau pesan dengan menggunakan bahasa rupa/ visual yang disampaikan melalui media berupa desain (Anggraini \& Nathalia, 2016; Kusrianto, 2007; Tinarbuko, 2008)

Bila dibagi berdasarkan kegunaan secara umum, terdapat 2 kategori pendekatan infografis, yaitu infografis eksploratif dan infografis naratif/narasi. Terdapat 3 aspek dalam pembuatan infografis di sebuah media massa, yakni aspek visual, aspek konten/data, aspek informasi. Tiga aspek tersebut terikat dalam 3 unsur dasar sebuah infografis, diantaranya utility, soundness, dan beauty. Sebuah berita maupun hasil penelitian yang dipublikasikan melalui media massa cetak maupun elektronik memerlukan infografis tidak hanya sebagai pemaparan berita, namun juga sebagai daya tarik 
media tersebut. Penggunaan warna, komposisi maupun elemen-elemen visual lainnya memperhitungkan keunikan maupun kekhasan dari sebuah media (Lankow, Ritchie, \& Crooks, 2014; Saptodewo, 2014)

Dalam bidang jurnalistik, infografis menjadi lahan keprofesian yang bisa mendapatkan keuntungan, seperti di negara maju perkembangannya cukup pesat dibanding penggunaan di dalam negeri, Menunjukan infografis menjadi prospektus tersendiri. Pada Infografis terdapat suatu konsep visual dalam bentuk struktur, sistematik, alur serta navigasi akan menjadi bagian penting sebagai ilmu dalam bidang komunikasi visual, dalam perjalanan kreatifnya diawali dari menemukenali permasalahan komunikasi visual, mencari data verbal dan visual, menyusun konsep kreatif yang berlandaskan pada karakteristik target sasaran, sampai tercapainya sebuah komunikasiverbal-visual yang fungsional, persuasif, artistik, dan komunikatif (Taufik, 2012). Saat ini banyak sekali jenis berita yang menyertakan infografis dalam tulisannya agar mempermudah pembaca untuk menangkap informasi secara cepat. Salah satu jenis berita tersebut adalah berita in-depth. Secara umum pengertian depth news reporting adalah pelaporan jurnalistik yang bersifat mendalam, tajam, lengkap, dan utuh mengenai suatu peristiwa fenomenal atau aktual. Dapat dikatakan bahwa depth news reporting merupakan produk dari berita investigasi. Dalam penulisan berita ini, reporter akan menghimpun informasi dengan fakta-fakta mengenai peristiwa yang dibahas sebagai tambahan informasi dari peristiwa tersebut. Jenis laporan ini memerlukan pengalihan informasi, bukan opini reporter. Biasanya in-depth news atau pelaporan mendalam disajikan dalam beberapa judul untuk menghindari kejenuhan pembaca. Pelaporan ini ditulis oleh tim, disiapkan dengan matang, memerlukan waktu beberapa hari atau minggu, dan membutuhkan biaya peliputan yang cukup besar.

Penjelasan diatas setidaknya membuat peneliti bertanya, apakah infografis mampu menyampaikan segala informasi yang disampaikan pada laporan in-depth? Berasal dari kata info dan grafis, dapat disimpulkan bahwa infografis kependekan untuk "grafis informasi". Informasi dalam konteks ini mengacu pada informasi atau berita dalam media massa. Secara umum infografis merupakan tanda isyarat visual untuk mengkomunikasikan informasi. Keunggulan komunikasi visual melalui infografis antara lain visualisasi gambar mampu menggantikan penjelasan yang terlalu panjang, serta menggantikan tabel yang rumit dan penuh angka (Lankow et al., 2014). Tentunya ini menjadi dasar bagi penulis untuk meneliti peran dan keterkaitan infografis sebagai pendukung berita pada kanal in-depth Tirto.id dan membuktikan apakah infografis mampu menggantikan penjelasan yang ada di dalam tulisan in-depth. Masalah ini menarik perhatian penulis karena berkaitan dengan kegiatan jurnalistik, maka sebagai pendukung berita tulis, sebuah infografis juga sebagai pendukung dalam produksi berita dan harus sesuai kaidah-kaidah jurnalistik yang ada. Oleh sebab itu, tujuan dari penelitian ini adalah: (1) Untuk mengetahui karakteristik infografis pada in-depth berita mengenai Penjarahan Bangkai Kapal di situs berita online Tirto.id; (2) Untuk mengetahui kedalaman infografis pada in-depth berita mengenai Penjarahan Bangkai Kapal di situs berita online Tirto.id; (3) Untuk mengetahui alasan digunakannya infografis pada setiap pemberitaan indepth di Tirto.id.

\section{METODE PENELITIAN}

Metode Penelitian yang digunakan dalam penelitian mengenai "Infografis 
SebagaiPendukung BeritaIn-depth Dalam Situs Berita Online" adalah kualitatif dengan pendekatan Studi Kasus. Metode kualitatif merupakan prosedur penelitian yang menghasilkan data deskriptif berupa kata-kata tertulis atau lisan dari orangorang dan perilaku yang dapat diamati (Moleong, 2000). Dengan kata lain, fokus penelitian kualitatifberada pada objek dan subjek yang dipilih oleh setiap penulisnya dan dibahas secara mendalam dan utuh (holistik). Sedangkan studi kasus adalah pencarian pengetahuan secara empiris yang: menyelidiki fenomena dalam konteks kehidupan nyata, bilamana: batas-batas antara fenomena dan konteks tidak tampak dengan tegas; dan di mana multisumber bukti digunakan. Selain itu penelitian ini juga dibantu dengan cara semiotika visual denotatif - konotatif untuk mengetahui makna-makna di balik infografis yang ditampilkan (Yin, 2003). Metode estetika yang digunakan untuk mengkaji nilai estetis sebuah infografis dari ragam hias, tema, pola, pengolahan data, komposisi, ilustrasi. Ikonografi juga merupakan persoalan ikon yang memperkatakan mengenai objek dan makna. Di dalam sebuah infografis data teks yang sudah ada diilustrasikan dalam bentuk simbol yang mempunyai makna (Saptodewo, 2014).

Teknik sampel dalam penelitian ini adalah purposive sample. Subjek penelitian ini adalah website atau situs berita Tirto.id dengan memilih satu judul berita in-depth yang menampilkan infografis di dalamnya. Peneliti memilih isu berita ini karena Tirto.id menjadikan isu penjarahan bangkai kapal sebagai headline news baik di website maupun di media sosial (Instagram) pada awal tahun 2018, dan berita "Misteri Raibnya Bangkai Kapal Perang Belanda di Laut Jawa" menjadi salah satu dari sekian banyak tulisan mengenai isu penjarahan kapal ini. Selain itu, peneliti menganggap bahwa kasus ini merupakan isu yang sangat serius karena penjarahan kapal di Indonesia merupakan kasus awam yang tidak banyak diketahui oleh publik.

\section{TEMUAN DAN PEMBAHASAN}

Proses pembuatan infografis di Tirto.id melalui beberapa tahapan. Data yang digunakan di infografis merupakan data valid dan sudah terverifikasi. Data tersebut didapat dari tim riset ataupun langsung dari reporter yang bertugas, kemudian diserahkan kepada tim visual. Setelah data berada di tangan tim visual, tim storyboard akan memilah data yang didapatkan untuk dimasukan ke dalam infografis. Setelah data-data dipilih, tim storyboard akan menyerahkan data tersbut kepada designer untuk dibuatkan visual data menjadi indografik. Proses akhir yakni saat infografis selesai, maka akan dilakukan pemeriksaan typo penulisan atau data dan infografis siap untuk disebarkan. Proses tersebut dapat dilihat pada GAMBAR 3.

Dalam tulisan in-depth, tentunya pembaca tidak dapat menangkap intisari berita hanya dengan membaca satu atau dua paragraf. Pembaca diharuskan mengikuti alur tulisan dari awal hingga akhir agar mengerti maksud dari tulisan tersebut. Hal tersebut tentunya akan memakan waktu yang cukup lama dibanding dengan membaca berita biasa. Di Tirto.id, setiap berita diberi keterangan waktu berapa lama umumnya berita tersebut dibaca. Rata-rata berita indepth dalam situs berita Tirto.id memiliki kapasitas waktu untuk dibaca selama 4 hingga 7 menit.

\section{Karakteristik Infografis Berita In- depth}

Tirto.id memiliki standar dalam membuat sebuah infografis, yakni memuat $60 \%$ ilustrasi dan $40 \%$ teks. Hal tersebut berlaku untuk setiap jenis infografis yang ditampilkan. Dapat dilihat dari beberapa contoh infografis milik 


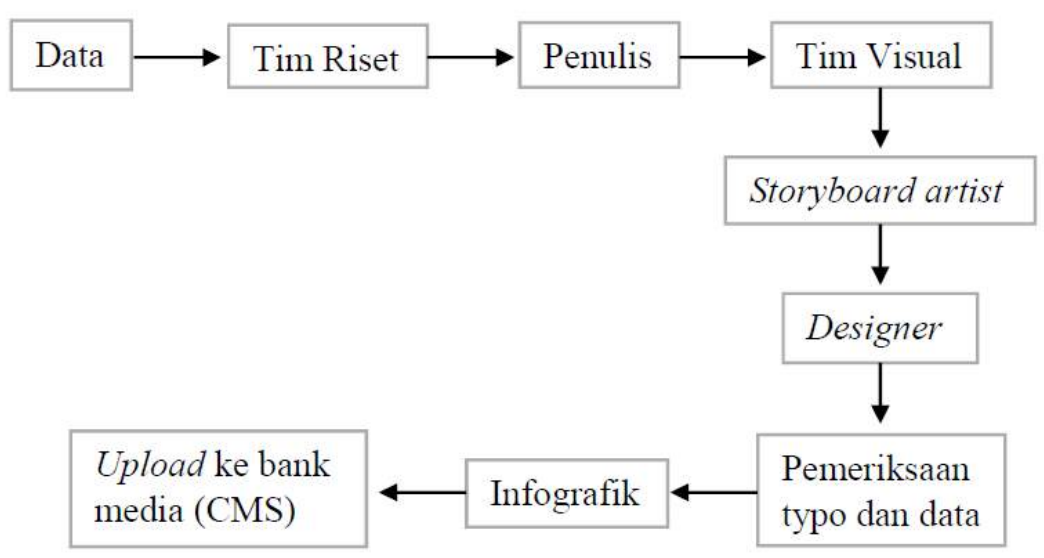

GAMBAR 3. Proses pembuatan infografis di Tirto.id

Tirto.id, isinya hampir dipusatkan kepada ilustrasi dan dibantu dengan beberapa teks. Pihak Tirto.id juga menjelaskan bahwa infografis yang mereka tampilkan tentu memiliki standar tertentu dan karakteristik. Infografis Indepth juga berisi rangkuman dari tulisan In-depth itu sendiri, namun tidak semua data yang berada dalam tulisan dimasukkan ke dalam infografis. Data-data yang masuk ke dalam infografis biasanya bersifat kompleks atau dalam arti data tersebut tidak dapat dimasukan ke dalam tulisan sehingga infografis harus mampu menyampaikan informasi tersebut. Infografis In-depth juga memiliki framenya sendiri dan ukuran yang berbeda dibandingkan dengan infografis lainnya.

Karakteristik lainnya adalah desain infografis yang digunakan selalu mengikuti trend dari waktu ke waktu. Desain tersebut meliputi gambar (ilustrasi), huruf/tipografi, warna, komposisi, dan layout. Dari penjelasan tersebut, maka dapat dikatakan bahwa infografis Tirto.id memiliki tiga poin

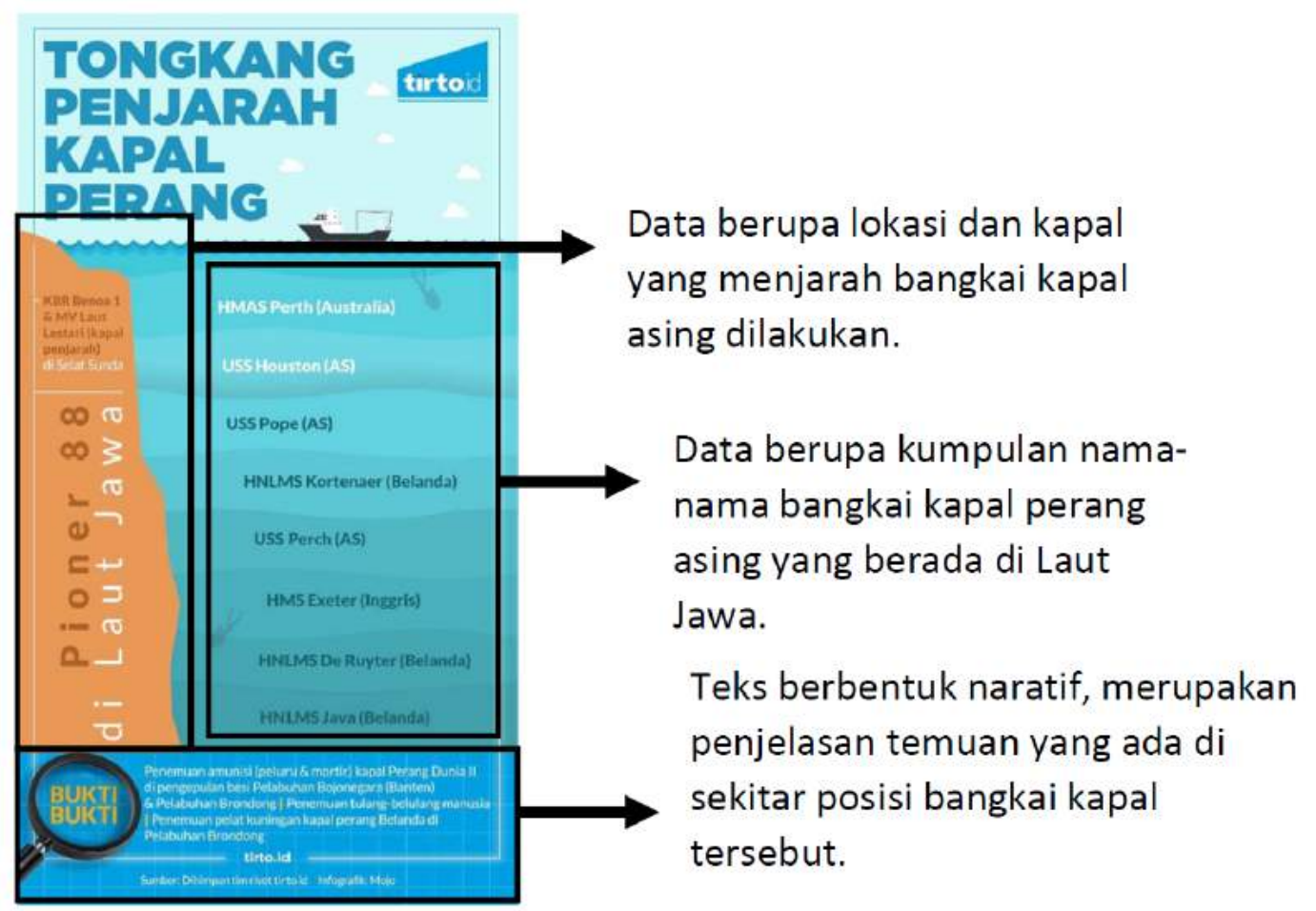

GAMBAR 4. Struktur Visual pada Layout Infografis Objek Penelitian 
utama yang menjadi karakteristik, yaitu teks (naratif), data, dan visual (GAMBAR 4).

Selain memiliki data, penggunaan warna-warna cerah dan desain yang lebih "bercerita" menjadi keunggulan dari infografis yang ditampilkan Tirto.id. Dari 3 unsur dasar yang harus dimiliki sebuah infografis, yakni Utility (kegunaan), soundness (makna), beauty (keindahan), infografis dalam berita 'Misteri Raibnya Bangkai Kapal Perang Belanda di Laut Jawa' masih kurang memenuhi syarat dari segi soundness (makna). Infografis yang bagus harus mengomunikasikan sesuatu yang bermakna. Menginformasikan pesan yang berharga memberi pembaca sesuatu yang bernilai. Meskipun infografis dapat menjadi sarana komunikasi yang kuat, terkadang pembuatannya asal-asalan dan tidak memiliki informasi yang penting dan menarik. Jika informasi itu sendiri tidak lengkap, tidak dapat dipercaya, atau tidak menarik, maka infografis tersebut tidak memiliki makna dan sia-sia. Dengan kata lain infografis yang baik harus memiliki makna dan integritas. Berdasarkan kuesioner responden, ternyata masih banyak pembaca yang kurang mengerti informasi yang disampaikan melalui infografis tersebut.

Pemahaman merupakan hal yang sangat menentukan dalam tujuan setiap bentuk komunikasi yang dilakukan. Tidak mungkin setiap bentuk kegiatan komunikasi dilakukan tanpa keinginan untuk memperoleh pemahaman dari publik. Berdasarkan beberapa penelitian terdahulu, pemahaman individu terhadap suatu konten dibedakan berdasarkan pemahaman situasional (situational understanding) dari individu/publik tersebut (Arigia Trie; Sani, Anwar, 2016). Jadi, pembaca yang melihat infografis hanya memiliki sedikit informasi, maka akan sulit untuk menarik kesimpulan terhadap isi infografis.

\section{Kedalaman Infografis dalam Mendukung Berita In-depth}

Laporan berita in-depth 'Misteri Raibnya Bangkai Kapal Perang Belanda di Laut Jawa' menceritakan isu hilangnya kapal perang Belanda yang karam di Indonesia. Dalam tulisan tersebut dijelaskan siapa saja dugaan pelaku penjarahaan, bagaimana proses bangkai kapal berukuran raksasa terseut dijarah, dan penemuan bom di sekitar lokasi penjarahan. Namun, tim storyboard

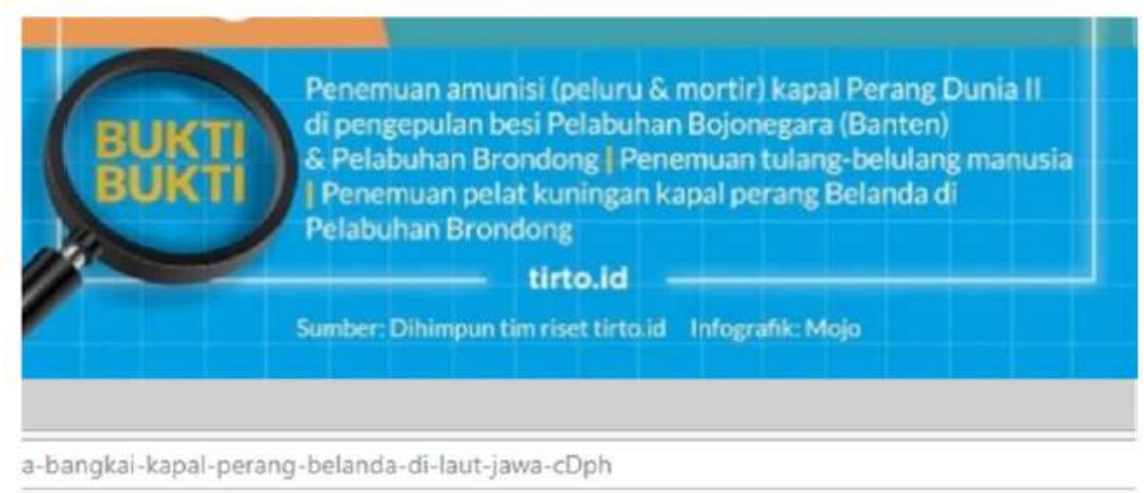

Penemuan Bom di Pelabuhan Brondong

Pada 7 November 2014, ditemukan amunisi dan bom berskala besar di area operasi PT Jatim Perkasa di Pelabuhan Brondong. Butuh lebih dari lima orang dewasa memindahkan bom berdaya ledak besar tersebut. Temuan puluhan mortir ini kemudian dibawa oleh personel Koramil setempat lalu diledakkan tim Gegana dari Polda Jatim di hutan Sedayulawas pada esok hari.

GAMBAR 5. Data pada infografis yang ada di teks berita in-depth 
hanya memasukan beberapa daftar kapal perang asing yang hilang di perairan Jawa, sedangkan nama-nama kapal perang yang hilang tidak disebutkan di dalam teks berita. Hanya nama kapal penjarah yang diduga sebagai alat untuk mengangkut bangkai kapal dan beberapa bukti penemuan saja yang dimasukkan ke dalam infografis dan merupakan bagian dari teks berita terkait (GAMBAR 5). Sepertinya hal ini kembali merujuk kepada kriteria yang sebelumnya sudah dijelaskan, bahwa standar dalam sebuah
$5 \mathrm{~W}+1 \mathrm{H}$. Walaupun demikian, infografis ini memuat data-data lainnya berupa gambar sehingga jika diperhatikan secara seksama, sesungguhnya infografis ini memuat data-data yang cukup mendalam. Karena pada dasarnya sebuah tulisan indepth fokus terhadap tulisan itu sendiri. Setidaknya melalui bantuan gambar dan teks data, dapat dilihat bahwa terdapat terdapat unsur what, where, dan who dalam infografis ini. Beberapa responden menyatakan bahwa tidak ada unsur how dan when pada infografis tersebut

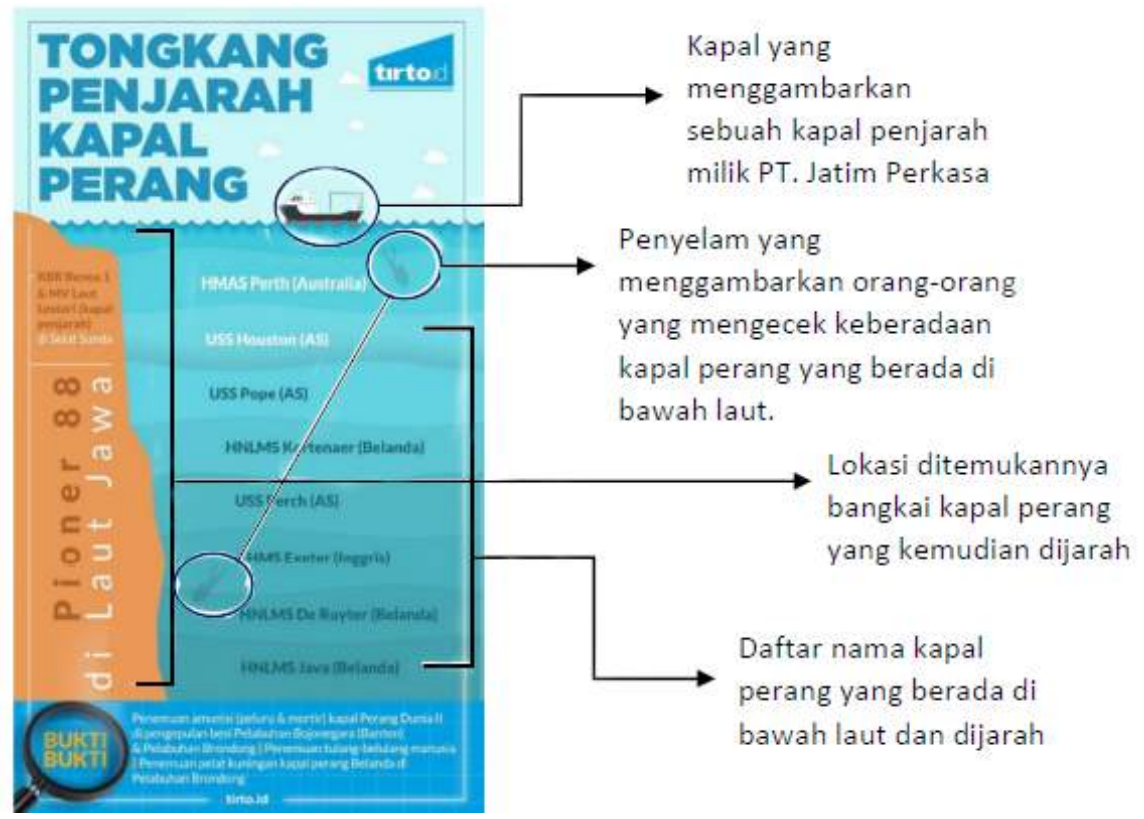

GAMBAR 6. Makna pada tiap gambar yang dimuat dalam infografis

infografis di Tirto.id hanya memuat $60 \%$ ilustrasi dan $40 \%$ teks. Teks tersebut didapat dari data-data yang diterima tim visual dari tim penulis atau tim riset. Data-data yang ada harus memuat unsur nilai berita $5 \mathrm{~W}+1 \mathrm{H}$ (what, when, why, who, where, how) dimana data tersebut merupakan rangkuman dari keseluruhan isi dari tulisan yang dimuat.

Jika melihat isi informasi dalam infografis terkait, kebanyakan responden merasabahwainformasiyangdisampaikan kurang dimengerti. Beberapa diantaranya juga mengatakan bahwa data-data yang dimasukan tidak mengandung unsur
(GAMBAR 6).

Peneliti menganggap bahwa tidak lengkapnya unsur $5 \mathrm{~W}+1 \mathrm{H}$ pada infografis infografis tersebut sebetulnya telah melengkapi keseluruhan teks berita yang hanya fokus kepada unsur berita how dan when. Dengan kata lain, pembaca tidak dapat hanya melihat infografis untuk mengerti informasi yang dibaca, melainkan harus membaca keseluruhan teks berita beserta dengan infografis yang disajikan agar informasi yang didapat lebih dimengerti.

Eksistensi Infografis dalam Berita In- 


\section{depth Tirto.Id}

Infografis pada Tirto.id digunakan untuk menarik perhatian pembaca. Disamping untuk menarik perhatian audiensnya, tujuan lain penggunaan infografis di Tirto.id adalah untuk menyampaikan informasi dalam versi ringkas dan easy-to-read yang berupa data kompleks dan menjadi medium untuk merangkum berita yang panjang. hal ini didukung dengan pernyataan dari Multimedia Manager Tirto.id, Sabda Armandio bahwa infografis di Tirto.id memiliki beberapa fungsi tetap yaitu: (1) Menyajikan data kompleks dalam bentuk visual; (2) Mempresisikan sebuah tulisan; (3) Merangkum tulisan; (4) Menarik perhatian pembaca (wawancara pada 24 Mei 2018).

Infografis yang digunakan adalah infografis naratif, dengan mengemas isi berita dengan alur yang menarik sehingga pembaca menerima pesan yang disampaikan melalui infografis tersebut. Hampir keseluruhan responden merasa infografis dalam sebuah tulisan indepth cukup menarik perhatian mereka. Infografis dijadikan sebagai bahan hiburan di tengah-tengah panjangnya tulisan yang dirasa membosankan. Dengan adanya suguhan ilustrasi gambar dan warna-warna yang cerah, membuat pembaca tidak merasa monoton saat membaca tulisan in-depth (GAMBAR 7).

Namun, berdasarkan penelitian infografis mengenai penjarahan kapal ini kurang memiliki daya tarik dibanding dengan infografis Tirto.id pada umumnya. Pemilihan warna yang terlalu monoton di keseluruhan infografis dan data yang masih kurang dimengerti oleh pembaca sehingga pembaca harus membaca infografis dan tulisannya secara berulangulang untuk mengerti keseluruhan informasinya. Namun, melihat tujuan Tirto.id menggunakan infografis sebagai penarik perhatian pembaca dirasa berhasil dan cukup efektif. Pada dasarnya, penggunaan infografis ini merupakan taktik pemasaran dan memang digunakan

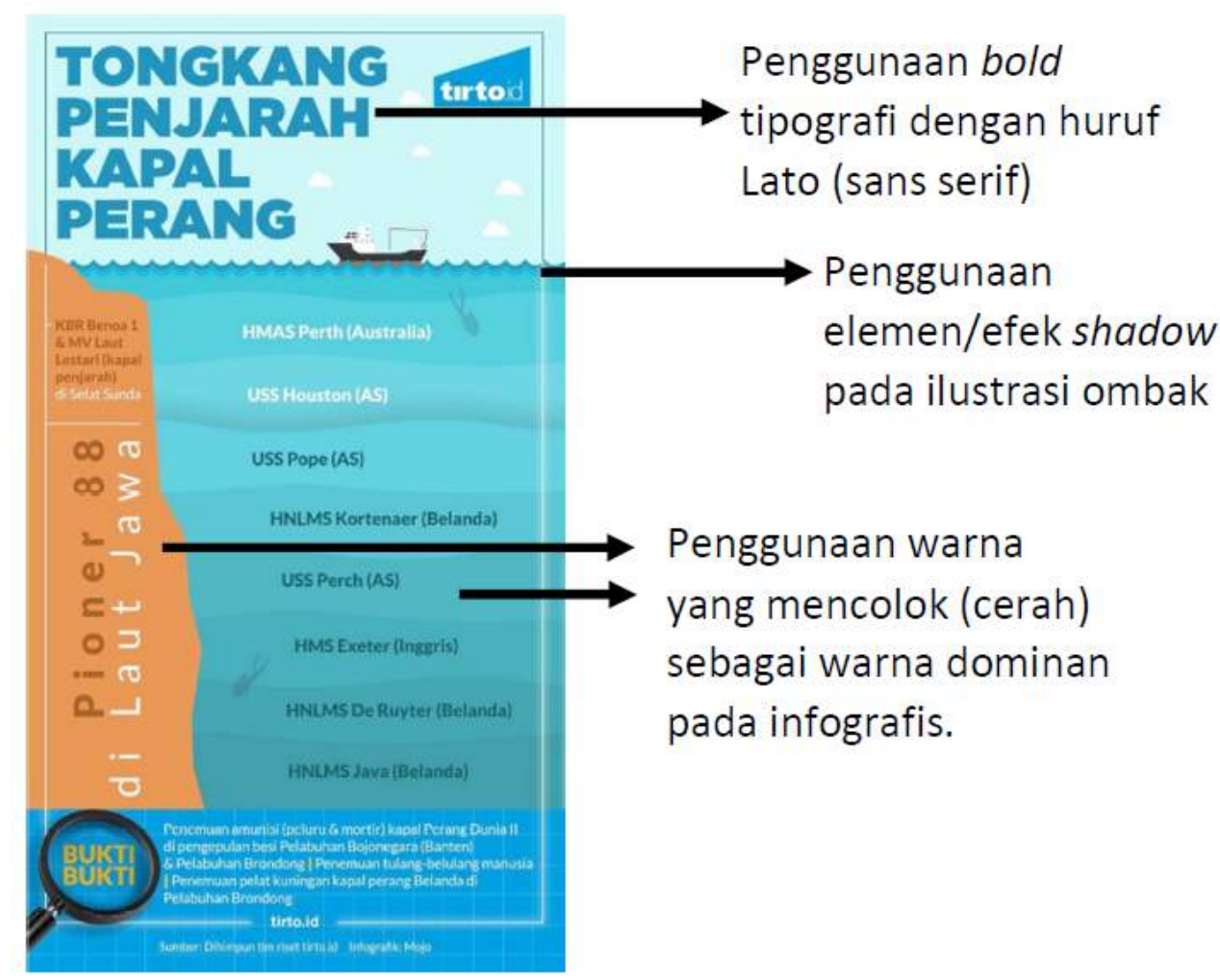

GAMBAR 7. Elemen Visual dalam Infografis 
untuk menjual "brand" kepada khalayak. Terbukti, Tirto.id mampu menjual "brand" kepada audiensnya melalui infografis ciamik-nya dan membutikan bahwa membaca sebuah berita panjang tidak harus selalu membosankan karena hadirnya infografis pada tulisan tersebut.

\section{SIMPULAN}

Dari hasil penelitian yang telah dilakukan maka dapat ditarik kesimpulan sebagai berikut: (1) Infografis yang disajikan Tirto.id pada tulisan in-depthnya memiliki beberapa karakteristik diantaranya penggunaan layout yang lebih formal dibandingkan dengan infografis non in-depth, isi yang dimasukan lebih bersifat kompleks dan memuat unsur nilai berita $5 \mathrm{~W}+1 \mathrm{H}$ yang merupakan salah satu kaidah jurnalistik. Penggunaan warna yang digunakan pada infografis Tirto.id menjadi ciri tersendiri karena mereka dengan konsisten menggunakan warna-warna cerah untuk menarik perhatian pembaca. Penggunaan ilustrasi pada infografis indepth tidak sebanyak infografis lainnya, karena mereka lebih fokus terhadap data. Infografis yang digunakan bersifat naratif karena teks yang dimasukan ke dalam infografis kebanyakan berupa teks narasi. Dalam proses pembuatannya pun infografis in-depth harus menunggu persetujuan dari reporter in-depth yang bersangkutan, sehingga baik tulisan maupun infografis yang ditampilkan memiliki kesinambungan; (2) Kedalaman informasi yang disuguhkan infografis in-depth dirasa masih kurang mengingat sebuah tulisan in-depth merupakan tulisan yang membahas suatu isu secara mendalam dibandingkan tulisan lainnya. Yang menarik adalah, jika fokus sebuah tulisan in-depth memuat tulisan mengenai how dan why, maka infografis in-depth akan memuat salah satu unsur dari what, when, where, dan who. Dengan demikian baik infografis in-depth dan tulisannya memiliki keterkaitan satu sama lain dan saling melengkapi. Namun, infografis yang dimuat dalam berita "Misteri Raibnya Bangkai Kapal Perang Belanda di Laut Jawa" masih kurang dimengerti oleh pembacanya. Kebanyakan pembaca masih merasa bahwa infografis yang ditampilkan kurang menjelaskan maksud dari inti tulisan yang dimuat; (3) Penggunaan infografis dalam sebuah berita in-depth tidak lain sebagai penarik perhatian pembaca. Stigma pembaca terhadap tulisan in-depth yang kerap kali dianggap membosankan karena format longform mampu dirubah sehingga pembaca pun lebih tertarik membaca tulisan panjang karena hadirnya infografis. Kehadiran infografis pada tulisan in-depth dirasa cukup efektif bagi pembaca karena infografis menjadi sebuah medium dalam merangkum isi berita dan memiliki aspek hiburan. Aspek hiburan tersebut ditinjau dari penggunaan warna dan ilustrasi dalam infografis sehingga pembaca tidak merasa bosan karena melihat warnawarna dan gambar yang menarik dalam tulisan in-depth. Walaupun menggunakan warna dan ilustrasi yang ceria, hal tersebut tidak meghilangkan sifat kompleks yang disuguhkan oleh tulisan itu sendiri. Tujuan lain penggunaan infografis di Tirto.id adalah untuk merangkum isi dari tulisan. Infografis yang disajikan memang merangkum isi tulisan, namun rangkuman yang ditampilkan bukan rangkuman keseluruhan sehingga untuk mendapatkan informasi yang utuh, pembaca harus tetap membaca keseluruhan isi berita sehingga memahami mengenai informasi yang disampaikan.

\section{DAFTAR PUSTAKA}

Anggraini, L., \& Nathalia, K. (2016). Desain Komunikasi Visual, Dasar-dasar Panduan Untuk Pemula. Bandung: Nuansa Cendikia.

Arigia Trie; Sani, Anwar, M. B. D. (2016). Infografis Sebagai Media Dalam 
Riyanti Hayuning Pratiwi, dkk. Infografis sebagai Pendukung Berita In-depth...

Meningkatkan Pemahaman Dan Keterlibatan Publik Bank Indonesia. Jurnal Komunikasi, (Vol 8, No 2 (2016): Jurnal Komunikasi), 120-133. Berger, A. A. (2008). Seeing is Believing, An Introduction to Visual Communication. New York: McGraw-Hill.

Kusrianto, A. (2007). Pengantar Desain Komunikasi Visual. Yogyakarta: Andi. Lankow, J., Ritchie, J., \& Crooks, R. (2014). Infographics The Power of Visual Storytelling. Jakarta: Gramedia Pustaka Utama.

Moleong, L. J. (2000). Metologi Penelitian
Kualitatif. Bandung: PT Remaja Rosdakarya.

Saptodewo, F. (2014). Desain Infografis Sebagai Penyajian Data Menarik. Jurnal Desain, 1(3), 163-218.

Taufik, M. (2012). Infografis Sebagai Bahasa Visual Pada. Techno.COM, 11(4), 156-163.

Tinarbuko, S. (2008). Semiotika Desain Komunikasi Visual. Yogyakarta: Jalasutra.

Yin, R. K. (2003). Studi Kasus (Desain dan Metode). Jakarta: Rajagrafindo Persada. 